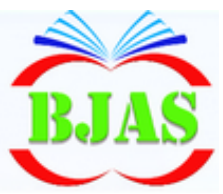

$$
\begin{aligned}
& \text { Available online at http://bjas.bajas.edu.iq } \\
& \text { https://doi.org/10.37077/25200860.2020.33.1.19 }
\end{aligned}
$$

College of Agriculture, University of Basrah

ISSN $1814-5868$

Basrah J. Agric. Sci., 33(1): 261-273, 2020
Basrah Journal of Agricultural

Sciences

E-ISSN: 2520-0860

\title{
Occurrence of Catoessa gruneri (Crustacea: Isopoda), Parasitic on Photopectoralis bindus from the Arabian Gulf with the First Description of its Male and Manca
}

\author{
Thamir K. Adday* \& Najim R. Khamees \\ Department of Fisheries \& Marine Resources, College of Agriculture. University of \\ Basrah, Iraq \\ *Corresponding author e-mail: addayt@yahoo.com \\ Received 19 September 2019; Accepted 18 November 2019; Available online 30 June 2020
}

\begin{abstract}
Orangefin ponyfishfish Photopectoralis bindus were collected during the period from January 2011 till June 2012 from the northwest of Arabian Gulf (29 $44^{\prime}$ to $29^{\circ} 49^{\prime} \mathrm{N}$ and $48^{\circ} 35^{\prime}$ to $48^{\circ} 51^{\prime} \mathrm{E}$ ). Fish samples were examined for parasitic infections. The isopod Catoessa gruneri Bowman and Tareen, 1983 was recorded from the gill pouch. Descriptions and some ecological aspects of females, males and manca larvae of the isopod were reported. The highest percentage of infection of manca was $98.8 \%$, while the highest levels of prevalence of infection was 1.8 in male. The present descriptions of the male and manca represent the first reports around the world.
\end{abstract}

Key words: Marine fish, Parasitic Isopod, Cymothoidae, Iraq.

\section{Introduction}

Orangefin ponyfish Photopectoralis bindus (Valenciennes, 1835), belongs to the family Leiognathidae. Its distribution being in Indowest Pacific, i.e from Port Sudan in the Red Sea and the Arabian Gulf to Japan, the Arafura Sea, and Australia. They live on muddy-sand bottoms of coastal waters, often enters estuaries. According to Froese and Pauly (2019) there are four valid species in the genus Photopectoralis.

The Isopods are a group of crustaceans belong to the class Malacostraca (Kabata, 1996). Some isopods are terrestrial, while many are aquatic, and some of them being parasites of fish. They are eumalacostracans including 119 different families (Martin and Davis, 2001). Cymothoidae is the only family that its adults seen on teleost fishes of marine and freshwaters in tropicals and sub-tropicals (Lester, 2005). Some of the young cymothoids burrow under the scales of their hosts while members of Lironeca are usually found beneath the operculum, it cause a marked pressure and atrophy of the adjacent gills (Kabata, 1996). Williams and BunkleyWilliams (1996) stated that the game fish chub mackerel along the Peruvian coast are parasitized by isopods, causing $15 \%$ loss of body weight and costing fishermen approximately 1.3 billion kilograms of fish 
annually. Lester (2005) mentioned that isopods harm the fish in several ways; mancae feed voraciously and easily kill fry and fingerlings; adult isopods stunt the growth of fish and inhibit reproduction. Farmed fish in many countries have been attacked by isopods, and plagued by tongue bites especially in Mediterranean maricuture and cages of sea bass in Chile and Australia (Lester 2005).The studies in Iraq dealing with parasitic isopods including: Ahmed (1970 a, b), Al-Daraji and Naama (1989) and AlDaraji (1995). Nevertheless, these studies are still poor and limited, so the present study focus on the new occurrence of harmful isopod Catoessa gruneri Bowman and Tareen, 1983 , which may turn to be a serious threat to the future mariculture and the adjacent inland aquaculture in Iraq.

\section{Materials \& Methods}

Fish collections were carried out during the period from January 2011 till June 2012 (Latitudes $29^{\circ} 44^{\prime}$ to $29^{\circ} 49^{\prime} \mathrm{N}$ and longitudes $48^{\circ} 35^{\prime}$ to $48^{\circ} 51^{\prime} \mathrm{E}$ ). Fishing gears were trawl nets with dimension of $75 \times 4 \mathrm{~m}$, drift gill nets with dimensions of $180 \times 4 \mathrm{~m}$. Fishes were removed from the fishing gears immediately on board of the fishing vessels separated individually in a selled plastic sacs with amount of water and ice, then kept on ice in icebox (54 x33 x30 cm) (Plumb and Bowser, 1983). Fish total lengths were measured up to the near $\mathrm{cm}$ on $58 \mathrm{~cm}$ fish measuring board and weighted to the nearest gm on balances model, sartorious $1.5 \mathrm{Kg}$ and mettler PE 3600 $4.5 \mathrm{Kg}$. Fishes were identified, based on Carpenter et al. (1997).

Fish examination started by checking the external surface to detect any parasitic crustaceans. Gills and mouth cavities were also detected. Isopods were removed using fine pointed forceps and kept in $80 \%$ alcohol (Yamauchi, 2009). Glass slides were prepared instead of the wooden slides which were conducted by Humes and Gooding (1964). The parasites were washed in $5 \%$ sodium hypochlorite to remove host tissue, and cleared in $85 \%$ lactic acidfor 1 to $2 \mathrm{~h}$ Khamees \& Adday (2013), the isopods were kept overnight on this slide. They were dissected, their appendages were removed, kept in $85 \%$ lactic acid on normal slide for overnight (Dr. N. Bruce, pers. comm., 30. 3. 2013). Body of the isopods were moisted, fixed on vaseline and examined under dissecting microscope and measured with the aid of digital vernair, while the appendages were measured using ocular micrometer. All measurement were in $\mathrm{mm}$. Ilustratiuons were prepaired with the aid of camera lucida fixed on dissecting microscope model Wild M 8, 2566575 (Switzerland).

\section{Results}

One hundred seventy specimens of Photopectoralis bindus (Valenciennes, 1835), were collected during the period from January 2011 till June 2012 from the northern west of the Arabian Gulf (Table 1).

Table (1): Mean prevalence, mean intensity of infection of $P$. bindus with $C$. gruneri.

\begin{tabular}{ccccccccc}
\hline $\begin{array}{c}\text { Isopod } \\
\text { gender }\end{array}$ & $\begin{array}{c}\text { No. } \\
\text { fish } \\
\text { Inf. }\end{array}$ & $\begin{array}{c}\text { Fish length } \\
\mathrm{cm}\end{array}$ & $\begin{array}{c}\text { Fish } \\
\text { weight gm }\end{array}$ & $\begin{array}{c}\text { fish No. } \\
\text { uninf. }\end{array}$ & $\begin{array}{c}\text { Fish length } \\
\mathrm{cm}\end{array}$ & $\begin{array}{c}\text { Fish } \\
\text { weight gm }\end{array}$ & $\begin{array}{c}\text { Per. } \\
\text { Inf. } \\
\%\end{array}$ & $\begin{array}{c}\text { Prv. } \\
\text { Inf. }\end{array}$ \\
\hline Female & 54 & $5.7-9$ & $11-11.1$ & 116 & $6.9-10.2$ & $8.3-18.2$ & 31.8 & 0.7 \\
\hline Male & 10 & $8.5-11.0$ & $8.1-20.3$ & 160 & $8.5-11.0$ & $10-20$ & 5.9 & 1.8 \\
\hline Manca & 2 & $9.6,10.2$ & $8.3,18.2$ & 168 & $5.7-11$ & $8.1-20.3$ & 98.8 & 1 \\
\hline
\end{tabular}




\section{Description Catoessa gruneri Bowman and Tareen, 1983 (Female):}

Fourty parasitic females were found attached in the branchial cavity and inner side of operculum of Photopectoralis bindus (Valenciennes, 1835). Two specimens of this parasite were deposited in the British Natural History Museum (NHMUK 2013.49-50). The description and measurements based on 11 specimens. Body (Figs. 1 A, B, C) 2.4 times as long as wide, being 10.6-16.6 mm (13.7 $\mathrm{mm})$ long and $5.2-6.1 \mathrm{~mm}(5.7 \mathrm{~mm})$ wide. It is widest at pereonites $4-5$, twisted to the left side $(55 \%)$, and $(45 \%)$ to the right side (Fig. 1 A, C), dorsum convex (Fig. 1 B, D). Cephalon pyriform, not deeply immersed with pereonites, narrowed anteriorly, and reflexed down into ventral lobe, narrowing frontwards. Eyes small about 0.30 width of cephalon and elongate about 0.26 of lateral margin of cephalon. Pereonites being $1<2<3<4>5>6>7$. Pereonite 6 being about 1.5 Pereonite 7 . Posterior margin of pereonite 7 is slightly indented. Coxae 2-6 are much shorter than their peronites (Fig. $1 \mathrm{D}$ ), while only coxa 7 is being slightly longer than its pereonite. Pereonite 7 overlaps pleonite 1 (Fig. 1 A, C). Pleonites 2-5 being as wide as pereonite 7, all about of the same length. Epimeria directed laterally, narrower than central parts of pleonites, and with gaps in between. Pleotelson small, semicircle in shape gradually narrowing distally. Antennule (Fig. 1 I) eight articled, long reaching anterior margin of pereonite 1 (Fig. 1 F), peduncle with three segments wider and longer apart, five distal flagellum segments short, small and being row of distal esthetes. Antenna (Fig.1 J) was slighty shorter more slender than antennule, 10 articled, gradually narrowing distally. Segments 3-10 bear one aesthetasc each, while there are three on distal article. Mandible (Fig. 1 K, L) with outer three segmented palp and broad incisor, distal segment of palp bears distal serrated spines. Maxillule (Fig.1 N, O) long, slender tipped with four apical spines. Maxilla (Fig. $1 \mathrm{M}$ ) robust tipped with two spines on outer lobe and one spine on inner lobe. Maxilliped (Fig.1 $\mathrm{P}, \mathrm{Q})$ three articled, proximal segment long and robust, second small, and distal segment smallest bearing three recurved spines. Pereopods (Figs. 1 R-U) all with broad bases excluding basis of pereopod 1. First preopod being smallest, while pereopod 4 being the largest. Ischium and merus being slightly broader than carpus and propodus. All pereopod tipped with strong, pointed and curved dactylus. Pleopods (Figs. 1 V-X) each consist of broad, semicircular branches, bearing gills or surface folds in addition to retinacula on pleopods 1-4. Uropods (Fig. 1 G) slightly extended beyond the telson, rami sublinear, narrowing distally, exopod slightly lower than endopod.

\section{C. gruneri Male:}

18 parasitic crustaceans were found attached to the branchial cavity of $P$. bindus, The description and measurements based on 10 specimens. Body being smaller than body offemale (Fig. 2 A) about 6.6-8.8 mm (8.1 $\mathrm{mm})$ long and $2.7-3.1 \mathrm{~mm}(2.9 \mathrm{~mm})$ wide. It is about 2.7 times as long as wide, widest at pereonite 4. Body untwisted, dorsum straight. Cephalon was as in female (Fig. 2 A, B), Eyes slightly larger than in female (Fig. 2 B), about 0.55 times width of cephaon, elongate about 0.33 times of lateral margin of cephalon. Pereonites being $1>2=3<4>5\rangle 6\rangle 7$. 

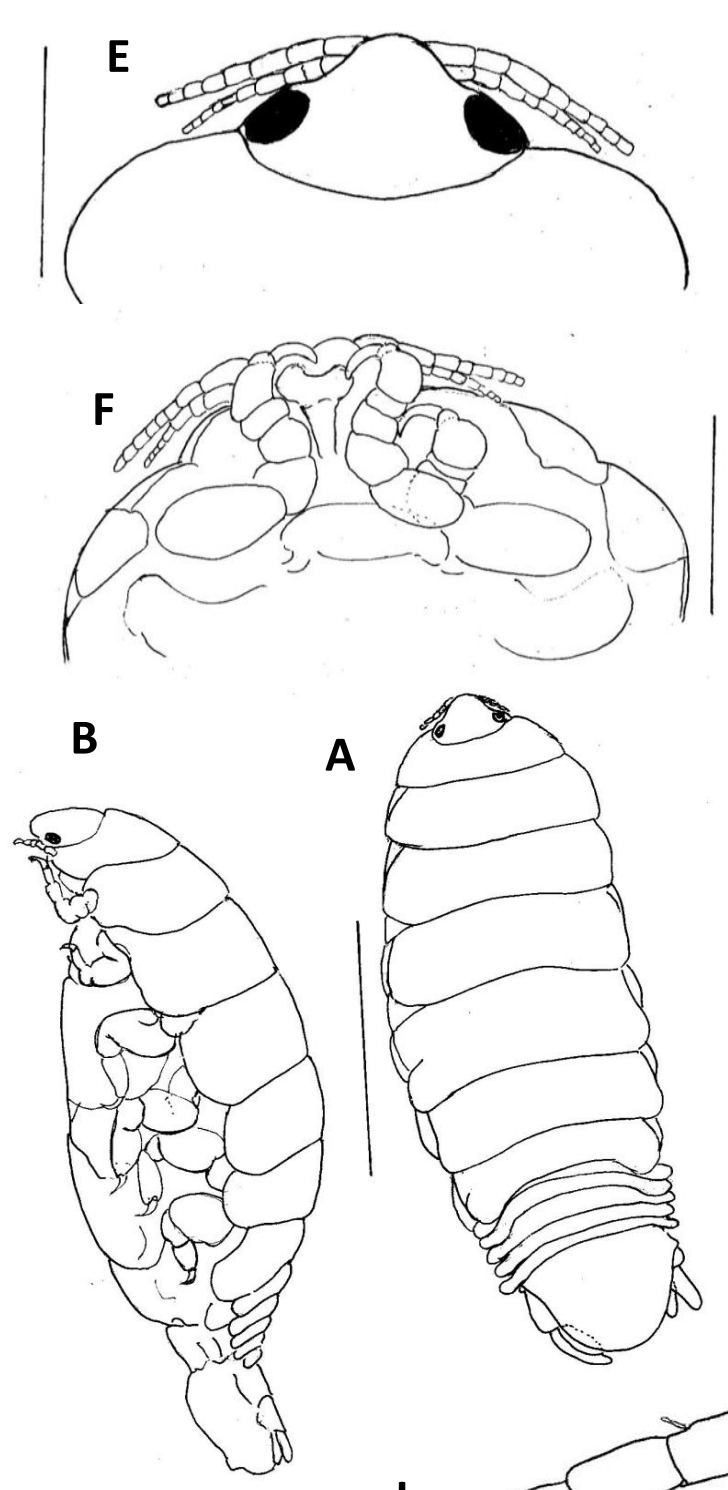

A
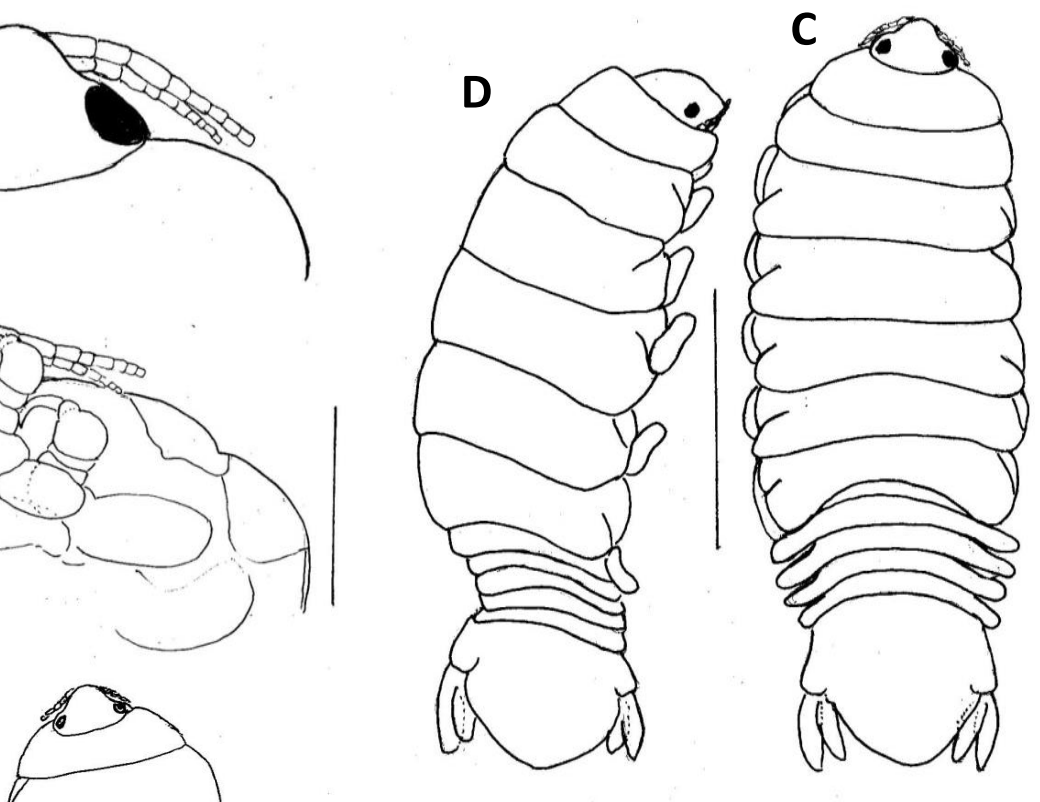

$\mathbf{G}$

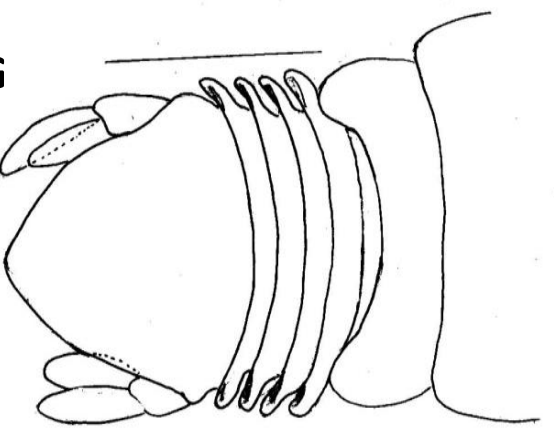

$\mathbf{H}$

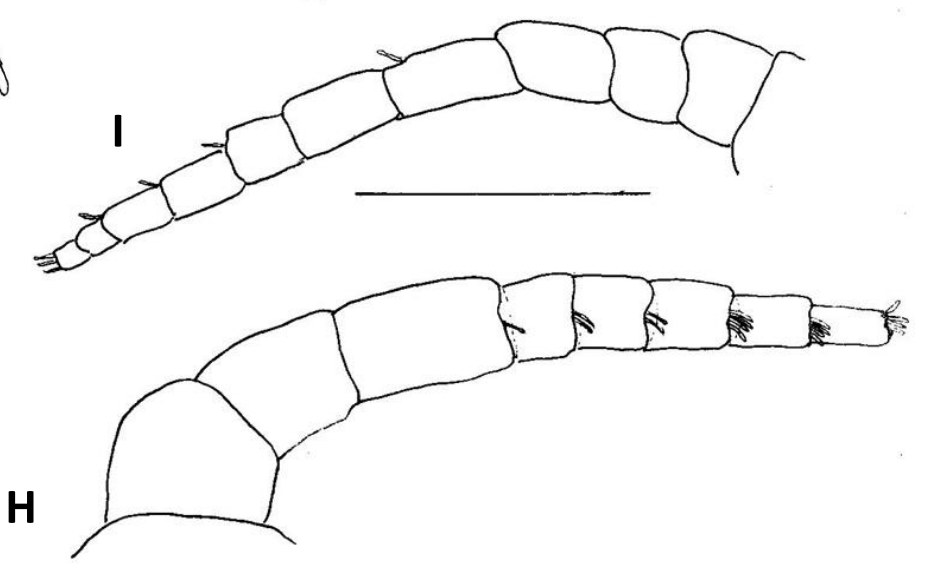

Fig. (1): Catoessa gruneri Bowman \& Tareen, 1983 Female

A habitus, dorsal; B lateral view, ovigerous; C habitus, dorsal; D lateral view, non-ovigerous; E cephalon; F cephalon, ventral view; G pleonites; $H$ antennule; I antenna (Scale bars 5.0 in A, B, C, D; 0.5 in E, F, G, H, I). 
Khamees \& Adday/ Basrah J. Agric. Sci., 33(1), 261-273, 2020

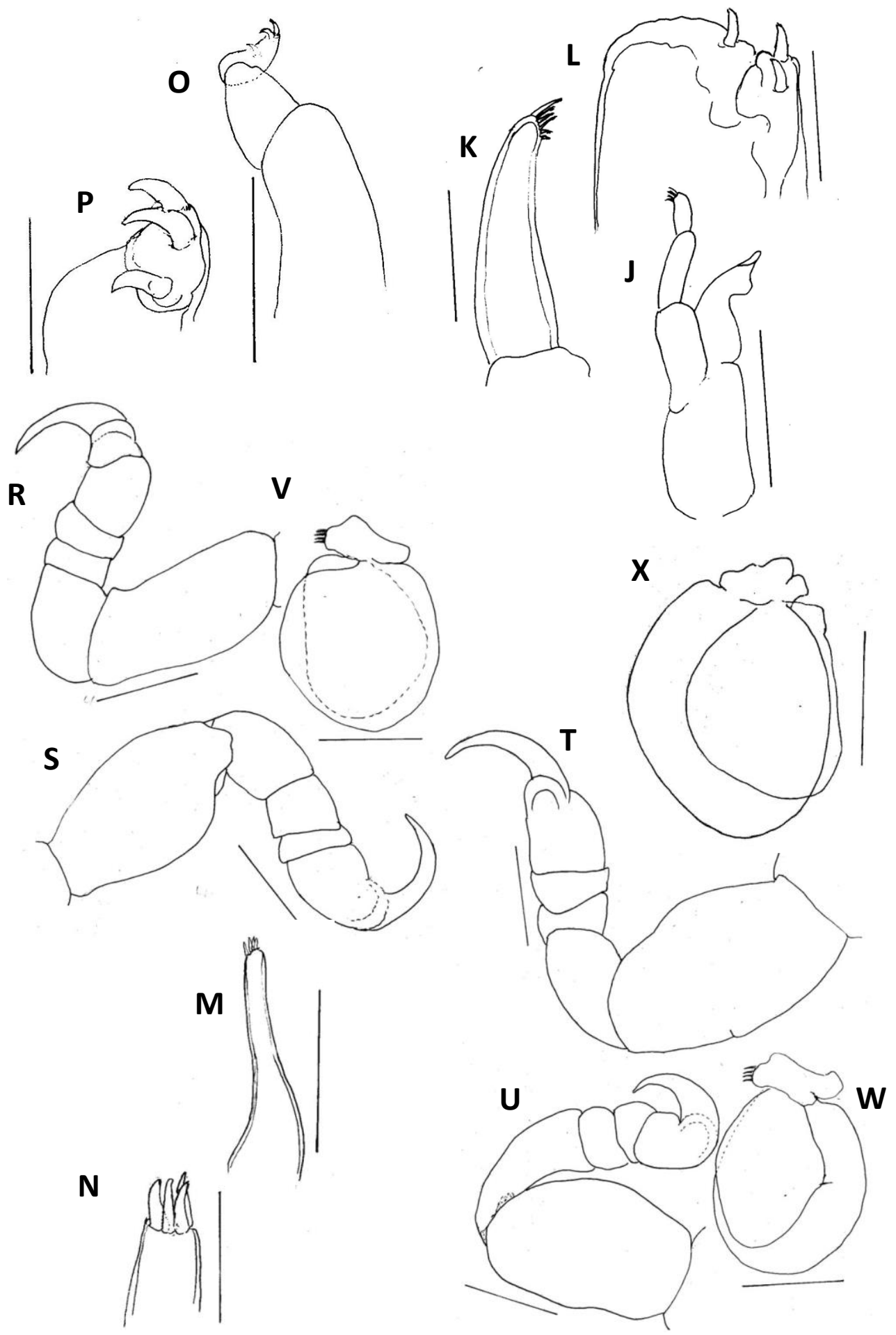

Fig. (1): Catoessa gruneri, female (cont.)

$\mathrm{J}$ mandible; $\mathrm{K}$ mandible palp distal; $\mathrm{L}$ maxilla; $\mathrm{M}$ maxillule, $\mathrm{N}$ maxillule apex; $\mathrm{O}$ maxilliped, $P$ maxilliped apex; $R$ pereopod 1; $S$ pereopod 2; $T$ pereopod 4; $U$ pereopod 7; $V$ pleopod 1; $W$ pleopod 2; X pleopod 5 (Scale bars). (Scale bars 0.5 in I, J, K, N, P; 1.5 in R, S, T, U, V, W, X; 0.1 in $\mathrm{L}, \mathrm{M}, \mathrm{O}, \mathrm{Q})$. 


\section{Khamees \& Adday/ Basrah J. Agric. Sci., 33(1), 261-273, 2020}

Pereonite 6 being about 1.3 times as long as pereonite 7. Posterior margin of pereonite 7 as in the female. Coxa of pereonites 2, 5 and 6 are long, while coxae of pereonites 3, 4 and 7 are much smaller than their pereonites. Pereonite 7 overlaps pleonite 1(Fig. 2 C). Pleonites 2-5 (Fig. 2 A) of the same width and slightly less wider than pereonite 7 , all about the same length. Epimera as in female. Pleoteson small, semicircular in shape narrowing posteriorly. Antennule slightly bigger than antenna, both about of the same length (Fig. 2 D, F). Articles as in female. Articles of both antennule and antenna bearing more aesthetascs than that of female. Mandible (Fig. 2 H, I), maxilla (Fig. 2 J), maxillule (Fig. $2 \mathrm{~K}$ ) and maxilliped (Fig. $2 \mathrm{~L}$, $\mathrm{M})$ all as in the female. Pereopods (Fig. 2 O$\mathrm{R}$ ) as in female. Pleopods (Fig. $2 \mathrm{~S}-\mathrm{W}$ ) as in female, except inner branches of pleopods 1 and 4 being smaller than outer branches. Appendix masculine being on a endopod of pleopod 2 (Fig. 2 T). Uropods (Figs. 2 X) being as in the female.

\section{C. gruneri Manca larva 2:}

Two manca larvae were found attached on the gills of $P$. bindus, The description and measurement based on two specimens. Body (Fig. $3 \mathrm{~A})$ being $2.74-2.80 \mathrm{~mm}(2.77 \mathrm{~mm})$ long and 0.88-0.90 mm (0.89 mm) wide, widest at pereonites 3-4, not twisted and flattend. Cephalon pyriform as wide as the anterior margin of pereonite 1. Eyes moderate 0.46 width of cephalon, elongate about 0.3 of lateral margin of cephalon. Pereon consists of seven pereonites but with 6 pereopods only, as pereonite 7 without pereopod. Pereonite 7 is much smaller than pereonite 6 , not overlaps pleonite 1 and without indentations. All pleonites about the same size but slightly narrowing backward. Pleotelson large, semi triangular in shape, posterior margin with marginal setae (Fig. 3 A). Antennule (Fig. 3 $\mathrm{B}, \mathrm{C})$ composed of eight articles extending to anterior part of pereonite 1, with two simple spiny short setae on antero-distal margin of articles 2, 3, 6 and 7 in addition to two large setae on distal margin of articles 4, 6 and 7, distal article tipped with 7 large setae. Antenna (Fig. 3 D) composed of 10 articles, slightly longer than antennule, with one seta on antero-distal margin of articles 2, two setae on antero-distal margin of articles 3, 7, 8 and 9, distal article slender with 7 unequal setae (Fig. 3 E). Mandible (Fig. 3 F), three articulated, proximal article longest, middle moderate and distal article small, selender with four setae increasing gradually in length along disto-lateral margin. Maxillule (Fig. 3 G) slender tipped with one robust curved spine and another three smaller spines. Maxilla (Fig. $3 \mathrm{H}$ ) as in the adults. Maxilliped (Fig. 3 I) was as in adults except that the basal and distal articles much larger. All pereopods (Fig. $3 \mathrm{~J}-\mathrm{O}$ ) were with acute dactyli and spines on pereopod 2, 4, 5 and 6, pereopod 2 with one spine on carpus and six on propodus; pereopod 4 with two spines on propodus; pereopod 5 with six spines on propodus; pereopod 6 with four very small spines on basis, one spine on each ischium and merus, two spines on carpus and six spines on propodus. Pleopods (Fig. 3 P-T) 1-4 were have protopod with coupling hooks and phyllopodus rami with long plumose setae except inner rami of pleopod 5. Pleopod 4 and 5 (Fig. $3 \mathrm{~S}, \mathrm{~T}$ ) with only the endopod ramus without plumose setae. 
Khamees \& Adday/ Basrah J. Agric. Sci., 33(1), 261-273, 2020

D

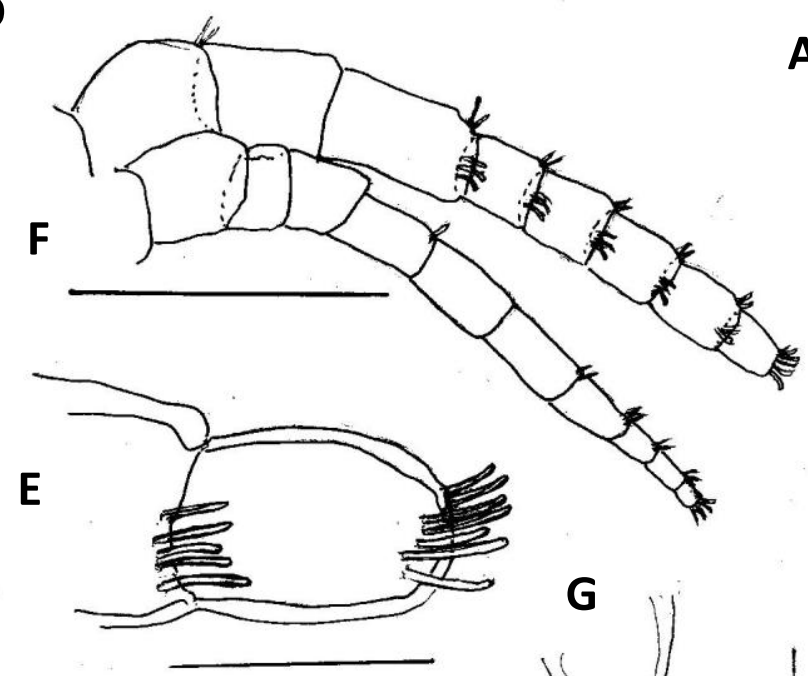

A

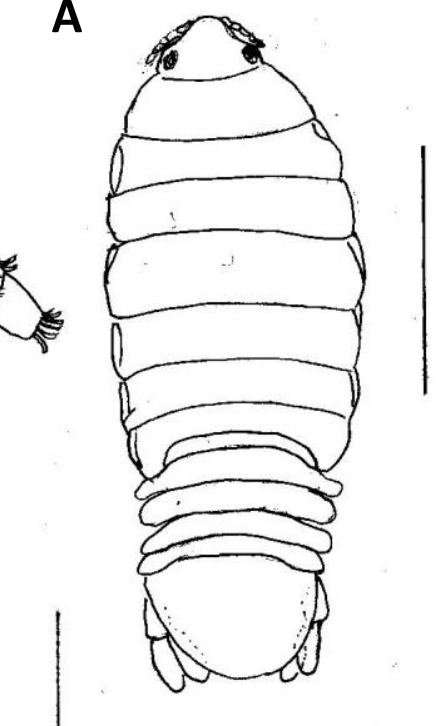

B

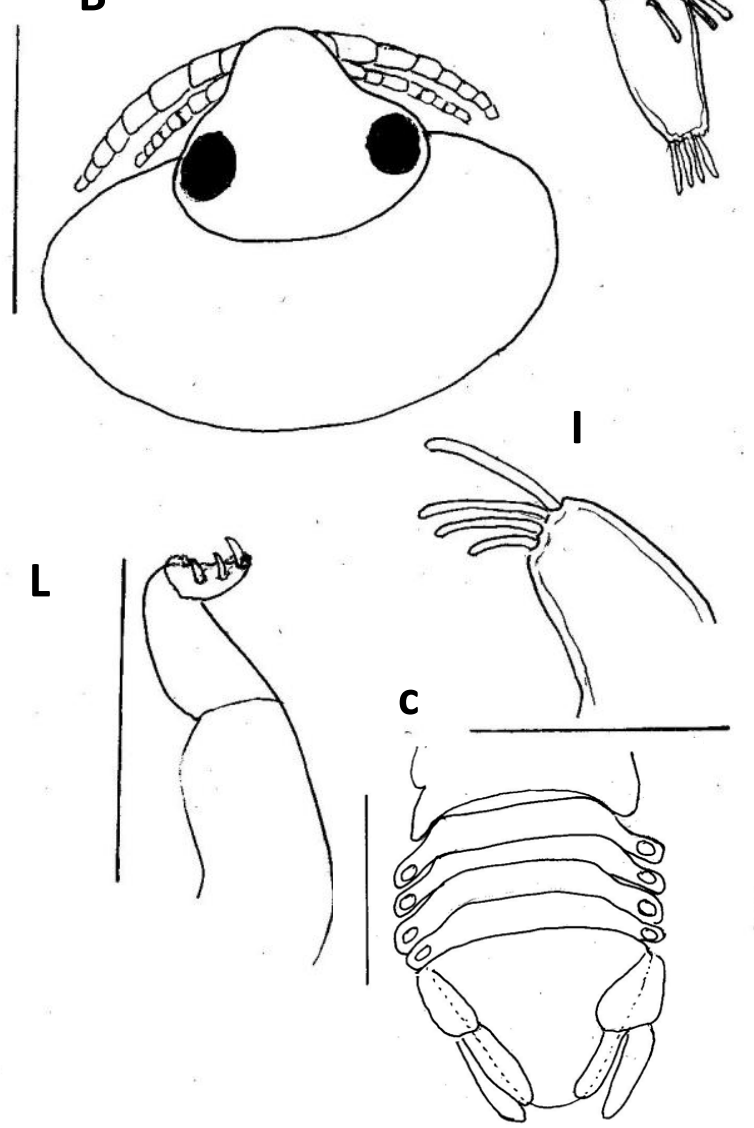

H

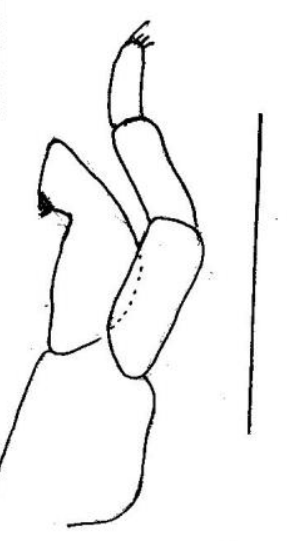

M

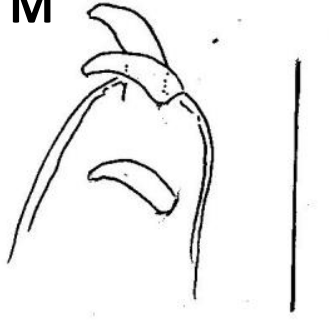

Fig. (2): Catoessa gruneri, male.

A habitus, dorsal; B cephalon; $C$ pleon, ventral view; D antennule; $E$ antennule distal articles; F antenna; $G$ antenna distal articles; $H$ mandible; I mandible apex; $L$ maxilliped; $M$ maxilliped apex (Scale bars 3.0 in A; 0.5 in B, D, M F, H, L; 1.5 in C; 0.1 in E, G, I, M). 
Khamees \& Adday/ Basrah J. Agric. Sci., 33(1), 261-273, 2020

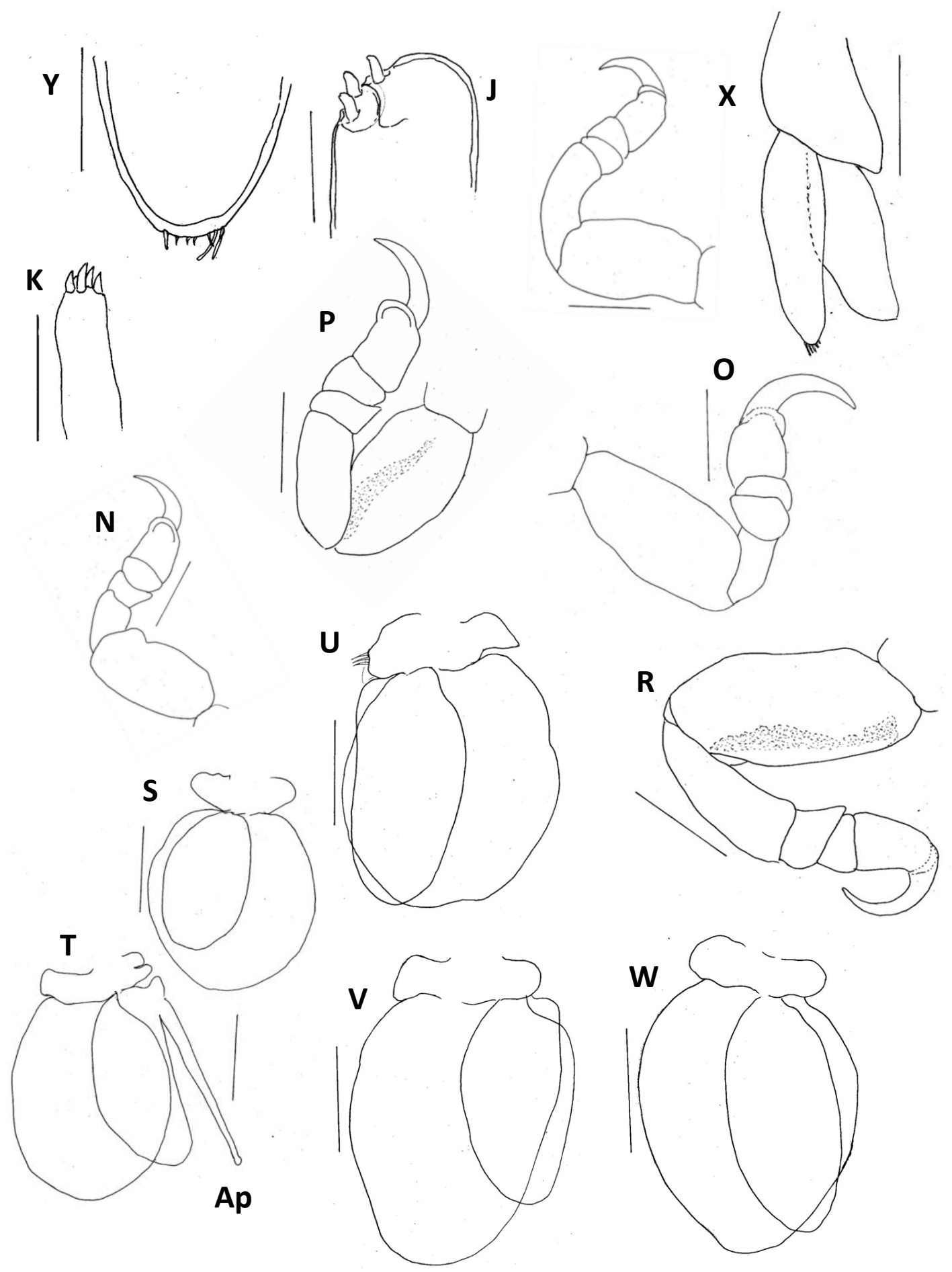

Fig. (2): Catoessa gruneri, male (cont.)

$\mathrm{N}$ pereopod 2; O pereopod 3; $\mathrm{P}$ pereopod 5; Q pereopod 6; $\mathrm{R}$ pereopod 7; $\mathrm{S}$ pleopod 1; T pleopod 2; $U$ pleopod 3; $\mathrm{V}$ pleopod 4, $\mathrm{W}$ pleopod 5; $\mathrm{X}$ uropod, $\mathrm{Y}$ distal margin of uropod exopodite; Ap appendix masculina (Scale bars 1.5 in C; 0.1 in J, K, Y; 0.5 in N, O, P, Q, X; 0.5 in $\mathbf{R}, \mathrm{S}, \mathrm{T}, \mathrm{U}, \mathrm{V}, \mathrm{W}$ ). 
Khamees \& Adday/ Basrah J. Agric. Sci., 33(1), 261-273, 2020
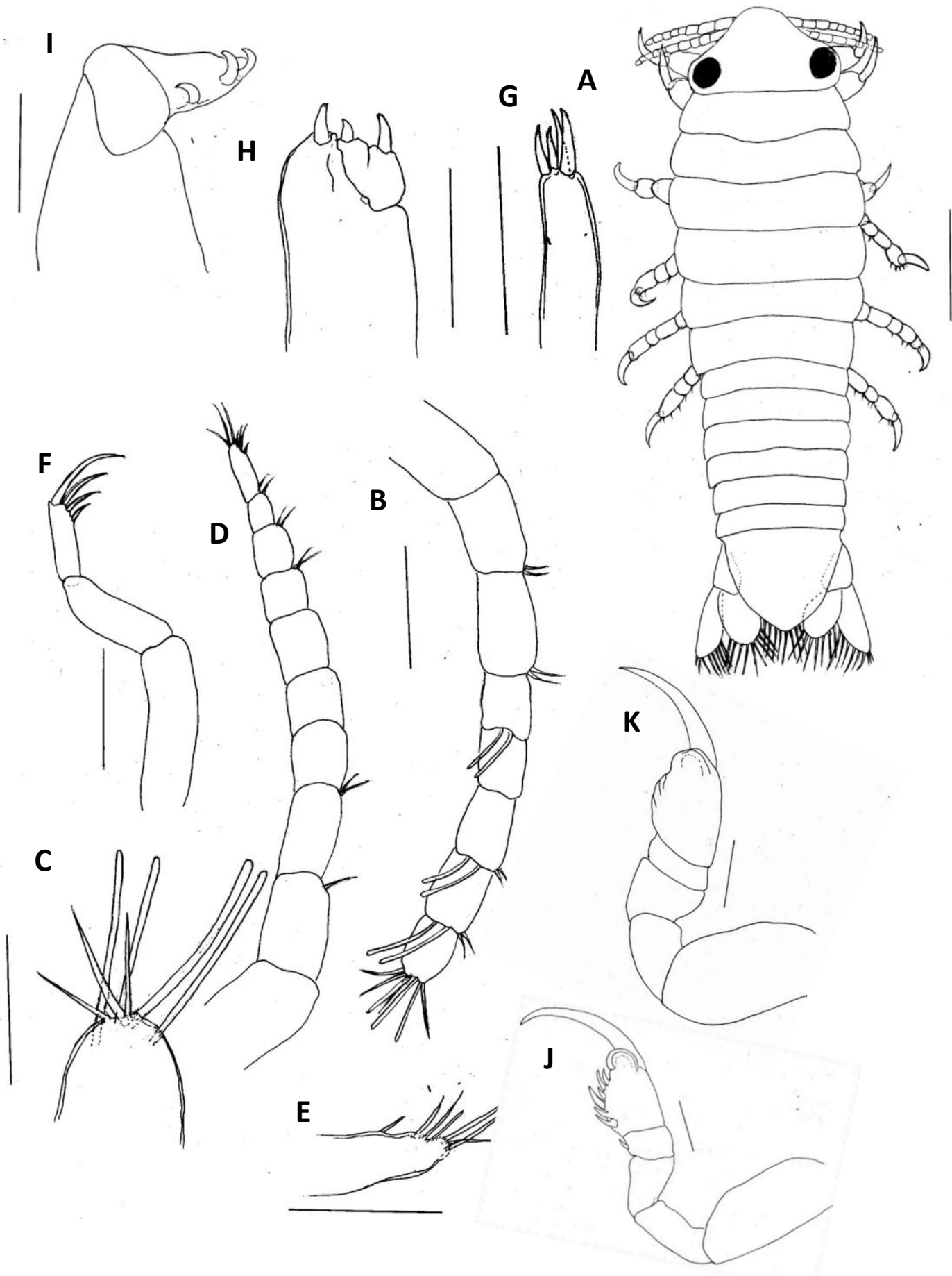

Fig. (3): Catoessa gruneri, manca larva 2

A habitus, dorsal, B antennule; C antennule distal article; D antenna; E antenna distal article; G maxillule; $\mathrm{F}$ mandible; $\mathrm{H}$ maxilla; I maxilliped; J pereopod 1; $\mathrm{K}$ pereopod 2 (Scale bars 0.5 in $\mathrm{A}, 0.1$ in $\mathrm{B}, \mathrm{D}, \mathrm{F}, \mathrm{J}, \mathrm{K} ; 0.05$ in $\mathrm{C}, \mathrm{E}, \mathrm{G}, \mathrm{H}, \mathrm{I})$.a 
Khamees \& Adday/ Basrah J. Agric. Sci., 33(1), 261-273, 2020

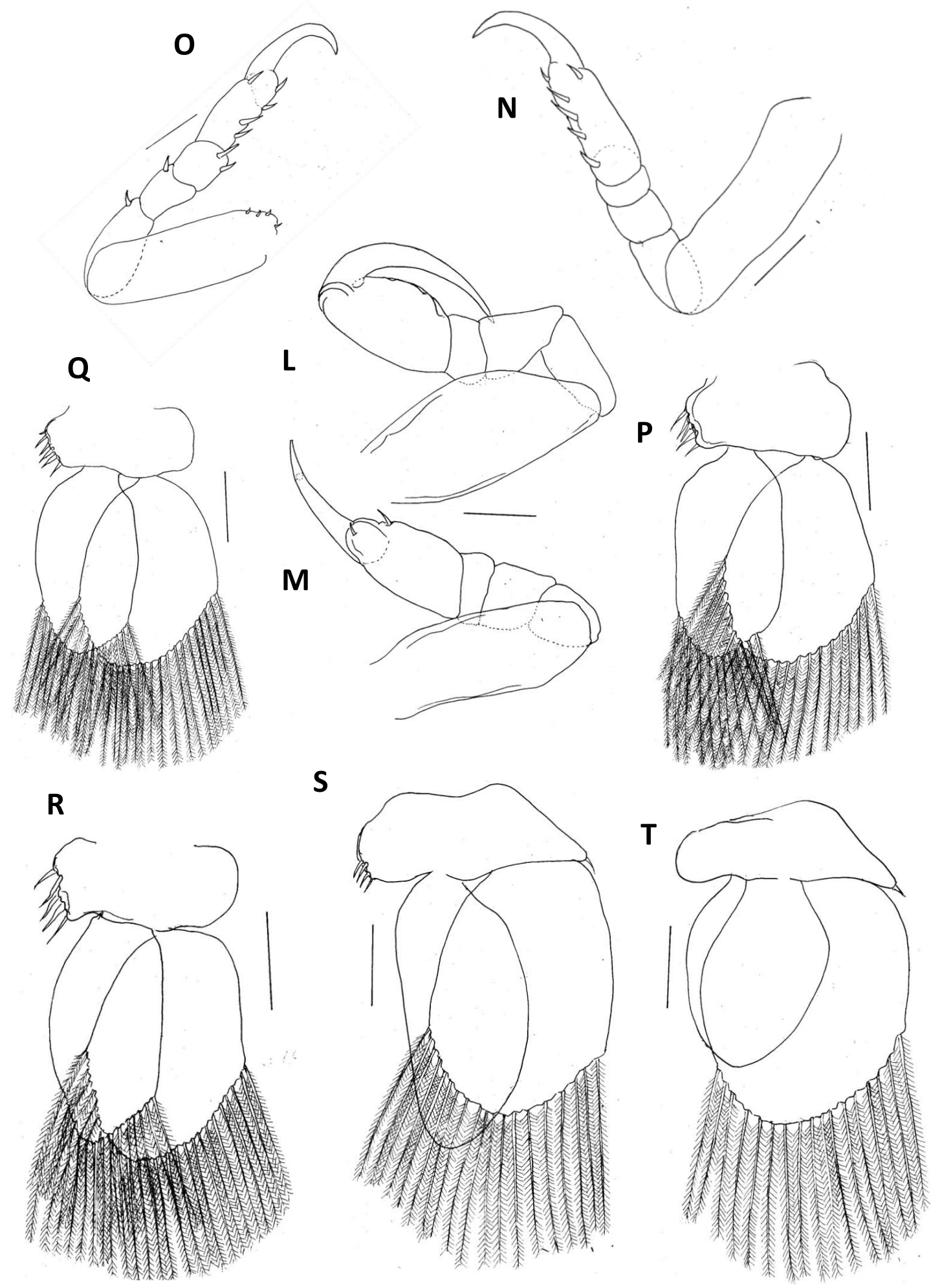

Fig. (3): Catoessa gruneri, manca larva 2 (cont.)

L pereopod 3; $M$ pereopod 4; $N$ pereopod 5; O pereopod 6; $P$ pleopod 1; $Q$ pleopod 2; $R$ pleopod 3; S pleopod 4; T pleopod 5 (Scale bars 0.1 in J, K, L, M, N, O, P, Q, R, S, T ). 


\section{Khamees \& Adday/ Basrah J. Agric. Sci., 33(1), 261-273, 2020}

\section{Discussion}

The family Cymothoidae consists of 43 valid genera with its oldest being Cymothoa Fabricius, 1787 and the most recent being Smenispa Özdikem, 2009 (Bruce and Schotte, 2013). Catoessa Schioedt and Meinert, 1884 is a valid cymothoid, includes four valid species, namely C. ambassae, C. boscii, $C$. gruneri and C. scabricauda (Shotte, 2013). All these species are marine parasites of teleosts. According to Dr. Niel Bruce (pers. comm., 16. 10. 2013) members of Catoessa can be easily distinguished from other members of the two close genera Elthusa and Livoneca by having more elongate and twisted body in addition to having gaps between the lateral margins of the pleonites. C. gruneri was reported as a new species from the gills of Leiognathus fasciatus [ now Aurigequula fasciata (Lacepéde, 1803)], L. daura [now Karalla daura (Cuvier, 1829)], Ilisha indica [now I. melastoma (Bloch and Schneider, 1801)] and Therapon puta, all were collected from the Arabian Gulf (Bowman and Tareen, 1983).

C. gruneri differs from the rest of species of the genus by having a rounded rostral point and posteriorly narrowed pleotelson (Bruce, 1990). Trilles et al. (2012) redescribed $C$. boscii based on numerous female and male specimens collected from the gills of Carangoides malabaricus from India, their attempt gave more detailed information of the morphology and ecology of this species. The same authors stated that this species was transferred from Livoneca by Bruce (1990). The specimens of $C$. gruneri of the present study were confirmed by Dr. Jean- Paul Trilles (Pers. comm. 16. 9. 2011) based on photos and detailed illustrations of camera lucida drawings. According to another communication with the same expert on 18. 5 . 2013, he confirmed that the present descriptions of the male and mancas of $C$. gruneri represent the first report around the world.

Al-Daraji (1995) reported this parasite in the buccal cavity of $L$. bindus [Photopectoralis bindus (Valenciennes, 1835)] and I. elongata, he proposed both fishes as new hosts for this isopod. In the present study the specimens are identical with that of the description of Bowman and Tareen (1983) and add additional descriptive information including the ratio of eye -head, body twist, general body measurements. According to J.-P. Trilles (pers. comm., 19. 9. 2011) the present record of $C$. gruneri represents its third occurrence from fishes of the Arabian Gulf from the same host.

\section{Conclusions}

Catoessa is a rare genus of the family Cymothoidae, includes only four valid species. C. gruneri is slightly a big parasite recorded from a small fish $P$. bindus. The first record of its male and manca larva in the world is documented.

\section{Acknowledgements}

Thanks are due to Prof. Dr. Jean-Paul Trille, Université Mont Pellise 2, France for confirming the identification of the parasite, and many thank to Prof. Dr Niel Bruce, Honorary Associate, Biodiversity \& Geosciences Program, Queensland Museum | South Brisbane, Queensland, Australia for his practial opinions in prepared and separated of Catoessa genus from other genera.

\section{Conflicts of interest}

The authors-declare-that they-have-noconflict of interests. 


\section{Khamees \& Adday/ Basrah J. Agric. Sci., 33(1), 261-273, 2020}

\section{Ethical approval}

All applicable institutional, national and international guidelines for the care and use of animals were followed.

\section{References}

Al-Daraji, S.A.M. (1995). Taxonomical and ecological studies on the metazoan parasites of some marine fishes of Khor Al-Zubair estuary, north-west of the Arabian Gulf. Ph. D. thesis, Univ. Basrah: $181 \mathrm{pp}$.

Ahmed, M. M. (1970). New Isopoda (Flabellifera) from Iraq and Arabian Gulf. III Icthyoxenus asymmetrica sp. nov. Bull. Iraq Nat. Hist. Mus., 4(2): 33-36.

Ahmed, M.M. (1970). New Isopoda (Flabellifera) from Iraq and Arabian Gulf. IV Nerocila heterozota sp. nov. Bull. Iraq Nat. Hist. Mus., 4(2): 55-58.

Al-Daraji, S. A. M. \& Naama, A. K. (1989). New records of three parasitic (Crustacean: Cymothoidae) from fishes of Khor AlZubair northwest Arabian Gulf, Iraq. Mar. Mesopot., 4(1): 83-95.

Bowman, T.B. \& Tareen, I.U. (1983). Cymothidae from fishes of Kuwait (Arabian Gulf) (Crustacea: Isopoda). Smith. Inst. Press, Wash., 1-30. https://doi.org/10.5479/si.00810282.382

Boyko, C.B.; Bruce, N.L.; Hadfield, K.A.; Merrin, K.L.; Ota, Y.; Poore, G.C.B.; Taiti, S.; Schotte, M.; Wilson, G.D.F. (Eds) (2008). World Marine, Freshwater and Terrestrial Isopod Crustaceans database. Cymothoidae Leach, 1818. Accessed through: World Register of Marine www. WoRMS. org. Accessed 28 Dec. 2019. https://www.marinespecies.org/aphia.php? $\mathrm{p}=$ taxdetails $\&$ id $=118274$
Bruce, N. L. (1990). The genera Catoessa, Elthusa, Enispa, Ichtyoxenus, Idusa, Livoneca and Nerocila n.gen. (Isopoda, Cymothoidae), crustacean parasites of marine fishes with descriptions of eastern Australian species. Rec. Austr. Spec., 42(3): 247-300. https://doi.org/10.3853/j.00671975.42.1990.118.

Carpenter, K.E.; Krupp, F.; Jones, D.A. \& Zajonz, U. (1997). The living marine resources of Kuwait, Eastren Saudi Arabia, Bahrain, Qater and the United Arab Emarates. FAO species identification field guide for fishery purpose, FAO, Rome: $293 \mathrm{pp}+\mathrm{XVII}$ pls. http://www.fao.org/3/v8729e/v8729e00.htm.

Froese, R. \& Pauly, D. (Eds.) (2019). Fish Base. World wide web electronic publication. www.fishbase.org., version (12/2019).

Humes, A.G. \& Gooding, R.U. (1964). A method for studying the external anatomy of copepods. Crustaceana, 6: 238-240. https://doi.org/10.1163/156854064X00650.

Kabata, Z. (2009). Chapter 34. Parasitic crustaceans. In Robert, LS. \& Janovy, J.Jr. (Eds.). Gerald D. Schmidt \& Larry S. Roberts Foundations of the parasitology, 8th edition, McGraw-Hill Co., New York: 537-559.

https://azdoc.tips/documents/foundationsof-parasitology-2-5c15f885b25cf.

Khamees N. R \&. Adday, T. K (2013). Occurrence of Sea Lice Caligus epinepheli Yamaguti, $1936 \quad$ (Copepoda: Siphonostomatoida) on Gills of Nemipterus japonicus (Bloch, 1775) from North West of the Arabian Gulf Basrah J. Agric. Sci., 26 (1): 1-14 (in Arabic). 
Lester, R.J.G. (2005). Chapter 4. Isopoda, 138-145. In: Rohde, K. (Ed.). Marine Parasitology. CSIRO publishing, 565 pp. http://www.vliz.be/en/imis?module=ref\&re fid=79470\&printversion=1\&dropIMIStitle $=1$.

Martin, J. \& Davis, G. (2001). An updated Classification of the recent crustacean. Crustaceana 39, Los Angeles Press: 124pp. https://www.academia.edu/9946076/An_U pdated_Classification_of_the_Recent_Crus tacea.

Trilles, J.-P.; Ravichandran, S. \& Rameshkumar, G. (2012). Catoessa boscii (Crustacea, Isopoda, Cymothoidae) parasitic on Carangoides malabricus (Pisces, Carangidae) from India. Taxonomic and host-parasite relationships. Acta Parasitol., 57 (2): 179-189. doi: 10.2478/s11686-012-0020-y. Epub 2012 May 13.

Williams, E. H. Jr. \& Bunkley-Williams, L. (1996). parasites off shore, big game sport fishes of Puetro Rico and the Westren North Atalntic, Univ. Puerto Rico Press, Mayagüez, Puert. Rico: 384pp. https://doi.org/10.2478/s11686-012-0020y. Epub 2012 May 13.

ظهور أناث القشري Catoessa gruneri (قشريات: متشابهة الأقدام) المتطفلة على أسماك الحصان برتقالي الزعنفة Photopectoralis bindus من الخليج العربي مع أول وصف للذكر واليرقة

$$
\text { ثامر قاطع عداي ونجم رجب خميس }
$$

$$
\text { قسم الأسماك والثروة البحرية، كلية الزراعة، جامعة البصرة، العراق }
$$

المستخلص: جمع 170 نموذج من أسماك ذيل الحصان برتقالي الزعنفة Photopectoralis bindus خلا المدة من كانون

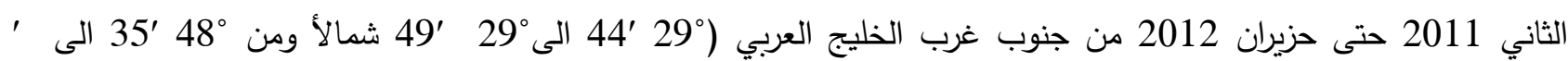
5148 شرقأ). فحصت الطفيليات لنماذج الاسماك المصابة. سجل متثابه الاقدام Catoessa gruneri من التجويف الغلصمي ووصفت الاناث والذكور ويرقة manca لمتثابه الاقدام الدفوص وسجلت بعض القياسات البيئية لها. كانت أعلى نسبة اصابة لليرقة 98.8\% وأعلى شدة اصابة للذكور كانت 1.8. يمثل الوصف الحالي للذكر واليرقة أول تسجيل لها حول 